\title{
Urinary phenolic acid and alcohol excretion in the newborn
}

\author{
F. KAROUM, C. R. J. RUTHVEN, and M. SANDLER \\ From Bernhard Baron Memorial Research Laboratories and Institute of Obstetrics and Gynaecology, \\ Queen Charlotte's Maternity Hospital, London
}

\begin{abstract}
Karoum, F., Ruthven, C. R. J., and Sandler, M. (1975). Archives of Disease in Childhood, 50, 586. Urinary pheholic acid and alcohol excretion in the newborn. Mean urinary excretion values of some phenolic acids and alcohols have been measured by gas chromatography in 44 neonates ( 36 males, 6 females) during the first 2 days and days 3-7 of life, and the effect of prematurity and jaundice assessed.

4-Hydroxy-3-methoxymandelic acid (VMA) output rises immediately after birth in term but not in preterm infants. A similar increase in homovanillic acid (HVA) output was restricted to nonjaundiced term babies; in nonjaundiced preterm babies there was a steady rise during the first week. The ratio of HVA to VMA output was higher in these infants than in adults, suggesting a more rapid turnover of dopamine than adrenaline and noradrenaline. Unlike adult values, both HVA and VMA excretion values were directly related to urine volume, an observation perhaps related to renal immaturity. An unexplained reduction in HVA output in jaundiced as opposed to nonjaundiced infants was observed in the first 2 days of life. The ratio of 4-hydroxy-3-methoxyphenylglycol to VMA was about the same as in the adult.

$p$-Hydroxyphenyl-lactic acid ( $p$-HPLA), because of its superior stability, was measured in preference to $p$-hydroxyphenylpyruvic acid as an index of tyrosyluria. An output of $1 \mathrm{mg} p$-HPLA/24 h is proposed as the upper limit of normal. Prematurity was associated with a significant rise in $p$-HPLA output. A dramatic increase in excretion of this acid was noted in jaundiced, compared with nonjaundiced infants, presumably a manifestation of general enzyme immaturity.
\end{abstract}

The importance of early detection of inborn errors of metabolism is well known. Although a truism, it is perhaps still worth stating that in order to identify abnormality the normal range must first be defined. The urinary excretion pattern during the newborn period of compounds relevant to this study often differs from that found in later life (Zeisel and Kuschke, 1959; Voorhess, 1967; Partington, 1968). It is likely that such differences may be ascribed to the effect of enzymatic (Boehm and O'Brien, 1963) and renal (McCance and Widdowson, 1954; McCance, 1959) immaturity and to differences between infant and adult diet.

Characteristic and grossly abnormal phenolic acid excretion patterns in the fully developed patient with phenylketonuria (Knox, 1972) or tyrosinosis

Received 3 January 1975.
(La Du and Gjessing, 1972), for example, are unmistakable. However, certain cases resembling these inborn errors of metabolism are observed where the biochemical defect is transitory because of temporary enzyme immaturity (Avery et al., 1967). Thus the names 'hyperphenylalaninaemia' (Menkes and Avery, 1963) or 'tyrosyluria' (Bloxam et al., 1960; Woolf, 1965; Wong, Lambert, and Komrower, 1967; Partington, 1968) have been applied to those conditions where immaturity of phenylalanine hydroxylase and $p$-hydroxyphenylpyruvic oxidase, respectively, may give rise to a biochemical pattern difficult to distinguish from that associated with absence of the enzyme. It is thus important to try to define each condition biochemically by determining the normal excretion range of the phenolic acids disturbed in these and allied pathological conditions. It is similarly important to determine the normal range of cate- 
cholamine metabolite output so that any significant increase is readily detected: it may facilitate the rapid diagnosis of one of the most common neoplasms of early life, the catecholamine-secreting neuroblastoma (Brett et al., 1964; Anders, Kindermann, and Pfeifer, 1973).

Although some quantitative information exists on the excretion of 4-hydroxy-3-methoxymandelic acid (VMA), a major metabolite of noradrenaline and adrenaline, in the neonate (von Studnitz, 1960; Gjessing, 1966; Nicolopoulos et al., 1968; Light et al., 1971), there are few comparable data for 4 - hydroxy - 3 - methoxyphenylglycol (HMPG), another important metabolite of these amines; for homovanillic acid (HVA) and 4-hydroxy-3methoxyphenylethanol (HMPE), major and minor metabolites of dopamine; and for certain other well known urinary metabolites of phenylalanine and tyrosine. This lack of information is no doubt due to the complex methods previously available for their determination, but the difficulty has now been overcome by using simple gas chromatographic techniques. In this way the excretion of a number of phenolic acids and alcohols has been studied quantitatively in infants during the first weeks of life.

\section{Material and methods}

Forty-four infants (38 males, 6 females born to healthy mothers at Queen Charlotte's Maternity Hospital), were chosen at random and classified into four groups.

(1) Term, nonjaundiced; gestation 39 weeks or more; birthweight $>2500 \mathrm{~g}$; peak serum bilirubin concentration not exceeding $5 \mathrm{mg} / 100 \mathrm{ml}$.

(2) Term, jaundiced; as (1) except that peak serum total bilirubin concentration was $>5 \mathrm{mg} / 100 \mathrm{ml}$.

(3) Preterm, nonjaundiced; period of gestation $<37$ weeks; birthweight $<2500 \mathrm{~g}$; peak serum total bilirubin concentration not exceeding $5 \mathrm{mg} / 100 \mathrm{ml}$.

(4) Preterm, jaundiced; as (3), except that peak serum total bilirubin range was $>5 \mathrm{mg} / 100 \mathrm{ml}$.

Measured 24-hour urine collections were made on most days of the first week of life in all infants. A few collections were made between the end of the first week and the end of the third. Urine samples were tested for keto acids using Phenistix and ferric chloride (Perry, Hansen, and MacDougall, 1966).

The gas chromatographic procedures used were as described previously (Karoum, Ruthven, and Sandler, 1968; Karoum et al., 1969). For the detection and estimation of phenolic acids, urine aliquots $(10 \mathrm{ml}$ if the 24-h volume was $<100 \mathrm{ml}$, or $15 \mathrm{ml}$ if it was $>100 \mathrm{ml}$ ) were taken for analysis. For specimens where a high excretion of $p$-hydroxyphenyl-lactic acid ( $p$-HPLA) was initially detected, $2-5 \mathrm{ml}$ urine volumes were employed for definitive analysis. Internal standards were added to a duplicate of every sample as follows: $0.1 \mathrm{mg}$ VMA, $0.1 \mathrm{mg} p$-HPLA, and $0.05 \mathrm{mg} \mathrm{HVA}$. Other metabolites were quantified employing the relative response of one of the internal standards, i.e. using the ratio of peak heights deriving from equal quantities of authentic metabolite and one of the internal standards run on a separate chromatogram under the same conditions.

Alcoholic metabolites (HMPG and HMPE) were similarly determined (Calne et al., 1969) in aliquots of urine hydrolysed with a sulphatase-glucuronidase preparation. HMPG $(0.1 \mathrm{mg})$ was added as internal standard to a duplicate of every urine specimen. Where small chromatographic peaks only were obtained for metabolites under investigation the analysis was repeated on a larger volume, using in some cases two levels of internal standard. Creatinine was measured by the method of Hare (1950). Serum bilirubin was estimated daily from birth to day 7 of life by the method of Lathe and Ruthven (1958).

\section{Results}

The Phenistix test was negative for all urine samples. Creatinine concentration, estimated in 22 infants during the first week of life, was variable with values ranging from 7-66 $\mathrm{mg} / 24 \mathrm{~h}$; significantly lower values were found in the preterm babies, both during days 1 and 2 and 3-7 of life. Creatinine output in jaundiced term infants was not determined; there was no significant difference between the levels found in jaundiced and nonjaundiced preterm infants.

Quantitative analytical data from the four groups are shown in Table $I$. The mean output of total HMPE was less than $50 \mu \mathrm{g} / 24 \mathrm{~h}$ and that for total HMPG $79 \mu \mathrm{g} / 24 \mathrm{~h}$ (observed range 10-252 $\mu \mathrm{g} / 24 \mathrm{~h}$ ) in all groups. The tendency for metabolite excretion values to be higher in premature compared with term infants when expressed as $\mu \mathrm{g} / \mathrm{mg}$ creatinine, but not as $\mu \mathrm{g} / 24 \mathrm{~h}$, arises from the low creatinine excretion of preterm infants.

The following urinary phenolic acids were measured in addition to those given in Table $I$. Though usually detectable, the output of $p$ hydroxybenzoic acid, and of $o$-and $m$-hydroxyphenylacetic acids, was less than $100 \mu \mathrm{g} / 24 \mathrm{~h}$. $m$-Hydroxybenzoic acid was not found. Vanillic acid was present in about $30 \%$ of the patients in amounts varying from $5-100 \mu \mathrm{g} / 24 \mathrm{~h}$.

In a few preterm jaundiced infants estimations of urinary $p$-HPLA and total serum bilirubin were made up to the age of one month. Though the bilirubin concentration dropped to values of about $5 \mathrm{mg} / 100 \mathrm{ml}$ or less within the first week of life $p$-HPLA excretion continued to be raised $(>1 \mathrm{mg} /$ $24 \mathrm{~h}$ ) for up to 2 or 3 weeks: occasionally output values dropped more rapidly during this period. 
Comparison of phenolic acid excretion between

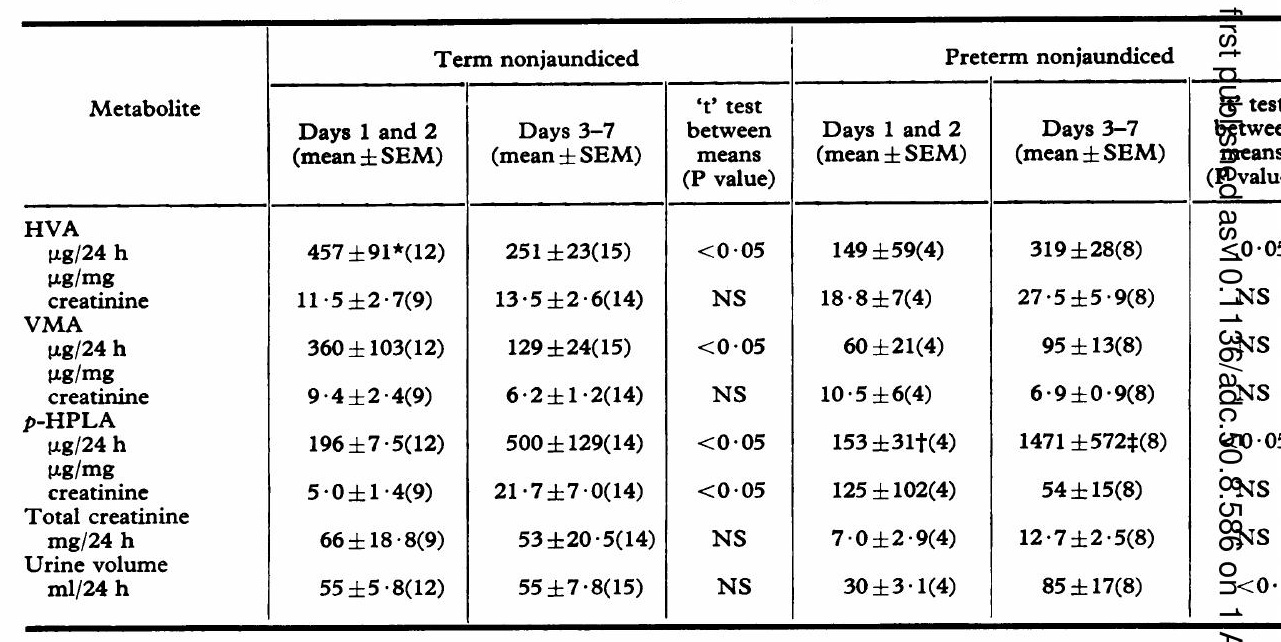

Note: Significance of difference between mean metabolite excretion values in nonjaundiced $\mathrm{v}$. jaundiced in $\star P<0.05 ;+P<0.02 ; \ddagger P<0.005 ; N S$, not significant.

Number of subjects in parentheses. HVA, homovanillic acid; VMA, 4-hydroxy-3-methoxymandelic acid; $p$-F楼LA p-hydroxyphenyl-lactic acid.

\section{Statistical tests}

Statistical analysis of results was based on the logarithms of recorded values, as this transformation appeared to create greater similarity of variance within groups. The data in each group were analysed in two parts, firstly those collected from birth to day 2 of life, and secondly those collected during days 3-7 inclusive. Means and standard errors of the mean (SEM) for the urinary output of each metabolite per day and per $\mathrm{mg}$ creatinine were calculated and the significance of their respective differences between groups, classified on the basis of maturity, presence of jaundice, and day of life, was compared using Student's ' $t$ ' test.

In comparing term nonjaundiced babies with preterm babies irrespective of jaundice (Table II), it was found that in the first 2 days of life 24-hour excretion values of HVA $(P<0.05)$ and VMA $(P<0.025)$ were lower in preterm infants; the opposite relation was found for the excretion of $p$-HPLA, calculated as both $\mu \mathrm{g} / \mathrm{mg}$ creatinine $(P<0.05)$ and $\mathrm{mg} / 24 \mathrm{~h}(\mathrm{P}<0.025)$. HVA and VMA output values calculated as $\mu \mathrm{g} / 24 \mathrm{~h}$ were not significantly different in preterm and term babies during days 3-7, though HVA excretion expressed as $\mu \mathrm{g} / \mathrm{mg}$ creatinine was significantly greater in both days 1 and $2(P<0.05)$ and days 3-7 $(P<0.025)$. Again the opposite effect was observed for $p$-HPLA during days 3-7, whichever way the excretion was expressed (Table II). Creatinine output in the urine was smaller $(P<0.05)$ in preterm than in term infants during the whole of the first week of life, whereas urine volume was found to be smaller in the former in the first 2 days only $(\mathbf{P}<0.001)$ (Table II). Comparisons of respective mean daily excretion values of HVA, VMA, and $p$-HPLA in jaundiced and nonjaundiced term babies for days 1 and 2 and 3-7 of life showed only three changes that were significantly different. HVA excretion was less $(P<0.05)$ in jaundiced than in nonjaundiced term infants on days 1 and 2, while $p$-HPLA was greater both on days 1 and 2 $(P<0.02)$ and days 3-7 $(P<0.005)$ in jaundiced compared with nonjaundiced preterm babies (Table I).

Statistical evaluation of differences within groups between days 1 and 2 and days 3-7 of life in daily urine volume and creatinine excretion, and mean excretion values of HVA, VMA, and $p$-HPLA expressed as $\mu \mathrm{g} / 24 \mathrm{~h}$ or $\mu \mathrm{g} / \mathrm{mg}$ creatinine, showed that some of these values changed significantly 48 hours after delivery (Table I). In the term nonjaundiced babies, HVA and VMA output values were higher $(P<0.05)$ in the first 2 days of life compared with the rest of the first week, when expressed as $\mu \mathrm{g} / 24 \mathrm{~h}$, but not when calculated on the basis of creatinine output. The reverse pattern was found in preterm nonjaundiced babies, daily HVA and VMA output values being higher in the latter part of the first week, though in this 


\section{I}

1 and 2 and days 3-7 of life in 4 groups of babies

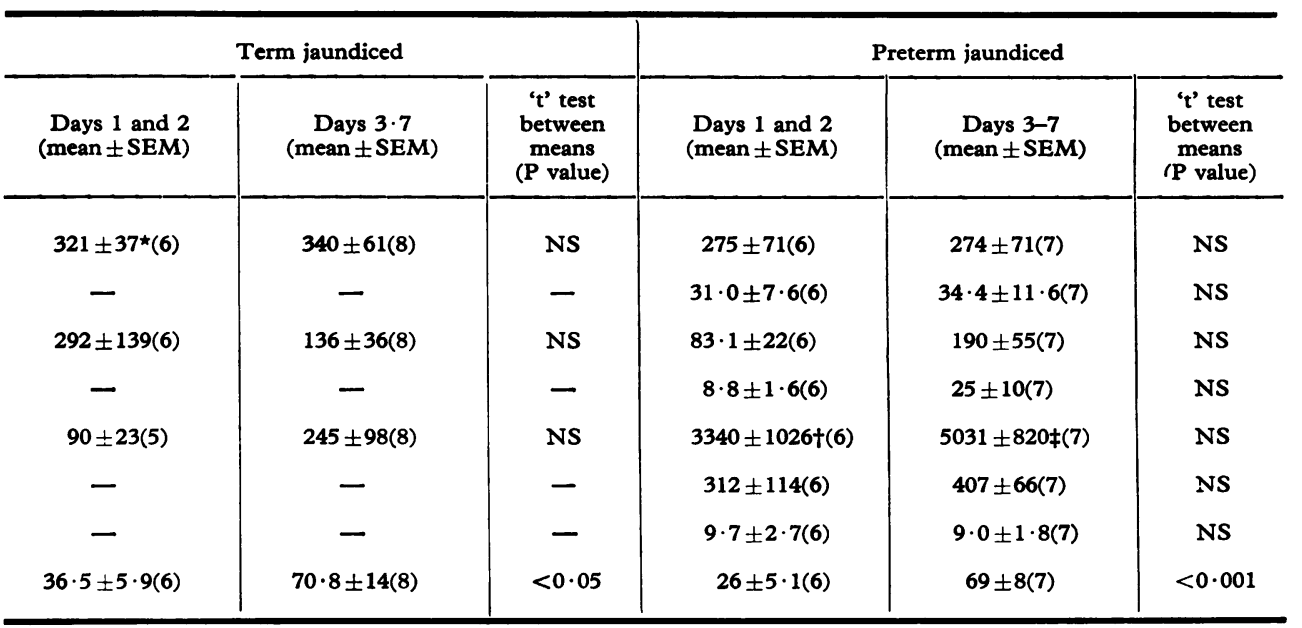

group only HVA excretion was significantly $(P<0.05)$ greater. $p$-HPLA excretion per day behaved like that in the term nonjaundiced infants, with a greater $(P<0.05)$ output after the first 48 hours, though in the term group there was a significant $(P<0.05)$ increase whichever way the values were expressed; in preterm babies $p$-HPLA excretion, calculated in terms of creatinine, was in fact greater in the first $\mathbf{4 8}$ hours, but not significantly so.

The mean 24-hour urine volume was significantly greater (Table I) during days 3-7 from birth taken in the first 48 hours after delivery in all babies except those in the nonjaundiced term groups where

TABLE II

Comparison of phenolic acid excretion in term and preterm babies irrespective of jaundice

\begin{tabular}{|c|c|c|c|c|c|c|}
\hline \multirow[b]{2}{*}{ Metabolite } & \multicolumn{3}{|c|}{ Days 1 and 2 of life } & \multicolumn{3}{|c|}{ Days 3-7 of life } \\
\hline & $\begin{array}{c}\text { Term* } \\
(\text { mean } \pm \text { SEM })\end{array}$ & $\begin{array}{c}\text { Preterm } \\
(\text { mean } \pm \text { SEM })\end{array}$ & $\begin{array}{c}\text { ' } t \text { '-test } \\
\text { between } \\
\text { means } \\
(P \text { value })\end{array}$ & $\begin{array}{c}\text { Term* } \\
(m e a n \pm S E M)\end{array}$ & $\begin{array}{c}\text { Preterm } \\
(\text { mean } \pm \text { SEM) }\end{array}$ & $\begin{array}{c}\text { ' } t \text { '-test } \\
\text { between } \\
\text { means } \\
(P \text { value })\end{array}$ \\
\hline $\begin{array}{l}\text { HVA } \\
\mu g / 24 \mathrm{~h} \\
\mu \mathrm{g} / \mathrm{mg} \\
\text { creatinine } \\
\text { VMA } \\
\mu \mathrm{g} / 24 \mathrm{~h} \\
\mu \mathrm{g} / \mathrm{mg} \\
\text { creatinine } \\
\text { p-HPLA } \\
\mu \mathrm{g} / 24 \mathrm{~h} \\
\mu \mathrm{g} / \mathrm{mg} \\
\text { creatinine } \\
\text { Total creatinine } \\
\text { mg/24 h } \\
\text { Urine volume } \\
\text { ml } / 24 \mathrm{~h}\end{array}$ & $\begin{array}{c}457 \pm 91(12) \\
11 \cdot 5 \pm 2 \cdot 7(9) \\
360 \pm 103(12) \\
9 \cdot 4 \pm 2 \cdot 4(9) \\
196 \pm 75(12) \\
50 \pm 1 \cdot 4(9) \\
66 \pm 18 \cdot 8(9) \\
55 \pm 5 \cdot 8(12)\end{array}$ & $\begin{array}{c}224 \pm 50(10) \\
26 \cdot 1 \pm 5 \cdot 4(10) \\
73 \pm 15 \cdot 3(10) \\
9 \cdot 4 \pm 2 \cdot 3(10) \\
2066 \pm 788(10) \\
237 \pm 81(10) \\
8 \cdot 6 \pm 1 \cdot 9(10) \\
27 \cdot 6 \pm 3 \cdot 2(10)\end{array}$ & $\begin{array}{c}<0.05 \\
<0.05 \\
<0.025 \\
\text { NS } \\
<0.025 \\
<0.05 \\
<0.05 \\
<0.001\end{array}$ & $\begin{aligned} 251 & \pm 23(12) \\
13 \cdot 5 & \pm 2 \cdot 6(9) \\
129 & \pm 24(12) \\
6 \cdot 2 & \pm 1 \cdot 2(9) \\
500 & \pm 129(12) \\
21 \cdot 7 & \pm 7(9) \\
53 & \pm 20 \cdot 5(9) \\
55 & \pm 7 \cdot 8(12)\end{aligned}$ & $\begin{array}{c}298 \pm 35(15) \\
30 \cdot 8 \pm 6(15) \\
139 \pm 28(15) \\
15 \cdot 3 \pm 5(15) \\
3136 \pm 668(15) \\
218 \pm 56(15) \\
10 \cdot 9 \pm 1 \cdot 6(15) \\
77 \pm 10(15)\end{array}$ & $\begin{array}{c}\text { NS } \\
<0.025 \\
\text { NS } \\
\text { NS } \\
<0.001 \\
<0.001 \\
<0.05 \\
\text { NS }\end{array}$ \\
\hline
\end{tabular}

$\star$ Term jaundiced babies omitted because creatinine was not determined on this group.

Note: Number of subjects in parentheses. 
the mean output was similar for both ages. Apart from the latter group there was a significant increase in daily urine output during days 3-7 compared with days 1 and 2 of life (Table I). The increase $(P<0.05)$ in urine flow recorded in term nonjaundiced infants compared to term jaundiced infants was not found on days 3-7 or in term babies at either age; however, ignoring any effect of jaundice, term babies put out more urine $(P<0.001)$ than preterm babies during days 1 and 2 but not subsequently.

Considering the first week of life as a whole, an examination of the effect of urine flow on the excrecretion of HVA, VMA, or p-HPLA showed that urine volume was significantly and positively correlated with the 24-hour output values of HVA and VMA and negatively with their concentrations, the correlations being stronger for HVA than for VMA. There was no connexion between $p$-HPLA output or concentration and urine volume.

\section{Discussion}

Catecholamine metabolites. The merits of expressing the output of urinary metabolites on the basis of creatinine excretion as opposed to 24-hour collections has been debated (Vestergaard and Leverett, 1958; Cramér, Cramér, and Selander, 1967; Applegarth, Hardwick, and Ross, 1968; Gitlow et al., 1968). The convenience of the former approach cannot be denied, particularly where a complete collection of the specimen is difficult, as in young children (Gitlow et al., 1968). Unfortunately, however, in this age group creatinine concentration is less reliable as an index of total urinary volume than at any other time (Applegarth et al., 1968). Alterations in renal function (Berlyne, 1965) and disturbances in normal feeding habits accompanied by weight loss (Pscheidt et al., 1966) have been reported to influence creatinine excretion in the adult. Renal, dietary, and metabolic factors undoubtedly exert an even greater effect on urinary creatinine levels in the newborn (Smith, 1959). The smaller muscle mass of preterm compared with term babies presumably accounts for the lower $(P<0.05)$ creatinine output found in the former. Therefore, in neonates in particular, it seems desirable to express metabolite excretion values in terms of a timed collection, or as concentration/unit volume (Cramér et al., 1967) if this is not possible, rather than link it to the highly variable creatinine output.

There have been a number of reports on the urinary excretion of VMA in the first week of life (von Studnitz, 1960; Boehm and O'Brien, 1963; Nicolopoulos et al., 1968) and at least one in the first month (Light et al., 1971). All values compared well with the present observations apart from those of Nicolopoulos et al. (1968) which are somewhat higher. Corresponding data for HVA in the neonatal period have only appeared recently (Melançon et al., 1974), though excretion values of both HVA and VMA in infants from the age of one month to one year were reported earlier by several groups (von Studnitz, 1962; Gjessing, 1966; Gitlow et al., 1968); these values range from $1 \cdot 2-35 \mu \mathrm{g}$ HVA/mg creatinine and from 1.4-15 $\mu \mathrm{g} \mathrm{VMA} / \mathrm{mg}$ creatinine. When comparisons are made on the basis of creatinine excretion, these levels are similar to those found by us (Table I), with the exception of preterm jaundiced infants where the value for VMA was slightly higher in the latter half of the first week of life (creatinine was not determined in term jaundiced infants). The results of Melançon et al. (1974) are expressed in terms of creatinine only and are confined to term babies. Like us, they found no significant change in HVA output during the first week though the levels given are somewhat higher than ours.

The reason for the lower HVA output (Table I) in jaundiced as opposed to nonjaundiced in the first 48 hours after birth is not immediately apparent. It can hardly be attributed to inhibition of an immature enzyme system by bilirubin as the effect was not observed in premature babies at this age or later in the first week of life. The increase in HVA output in term nonjaundiced infants in the 48 hours after birth was not detected in the other groups; in fact, in nonjaundiced premature babies there was an increase in the latter part of the first week, with a trend in this direction in term jaundiced infants (Table I). A lower output of VMA in the preterm compared with the term infant was observed in the first 2 days of life (Table II). In term infants 2 to 3 weeks old, Light et al. (1971) noted a decrease in urinary adrenaline excretion and an increase in urinary VMA output when serum tyrosine was raised. Because of slight differences in age and in criteria used for selection of groups, Light's and our VMA results do not compare exactly. However, in jaundiced preterm babies, where tyrosinaemia is more marked than in other infants, there was a tendency for VMA excretion to be higher during days 3-7.

After the first few days of life noradrenaline and adrenaline excretion is higher on a weight for weight basis in the newborn than in adults (Zeisel and Kuschke, 1959), though the ratio of dopamine to noradrenaline remains proportionately the same 
(Stern, Greenberg, and Lind, 1961). These observations point therefore to a raised output of dopamine in the newborn compared with the adult, an impression which has received direct support from Voorhess (1967). In the light of the consistency in the relation between the two amines irrespective of age, the tendency toward an agedependent alteration in ratios of their major acidic metabolites, HVA and VMA (see below), may be a further example of a difference between neonatal and adult renal excretion mechanisms, and/or rate, and route of metabolism. Voorhess (1967) speculated that the greater output of dopamine and noradrenaline per unit body surface area which she noted during the first year of life, might be related to rapid growth and maturation of the sympathetic nervous system at this time. The same argument might apply to the increase of catecholamines per unit body weight observed by Zeisel and Kuschke (1959) in the first year of life. However, in all work of this kind, including that described here, it is not immediately obvious whether variations in output stem from alterations in catecholamine synthesis, change in rate of release from storage granules, or alterations in degradation pathways. The higher HVA to VMA ratio observed in the neonates (Table I), with a mean of about 1.5 and a range of approximately 1-3, which are considerably higher than the value of about 1 found in normal adults, strongly indicates a somewhat faster dopamine turnover than adrenaline and noradrenaline.

The direct association between urine volume and both HVA and VMA output observed during the first week of life is a further illustration of a functional difference between the neonate and older child or adult, a difference which presumably derives from immaturity of the neonatal kidney (Smith, 1959). Using a spectrophotometric procedure (Pisano, Crout, and Abraham, 1962) to estimate VMA, Ruthven (1965) also observed a significant correlation $(P<0.01)$ between VMA excretion and urine volume in the neonate. Immaturity of the neonatal kidney presumably accounts for the increase in daily urine output observed after the first 2 days of life, particularly as this was most marked in the preterm infant, though in part at least the lower urine flow in preterm babies (Table II) is probably associated with their smaller body weight.

Von Studnitz (1960), in a study of a small number of newborn infants, noted an increased VMA excretion on day 1 of life compared with day 3 , which agrees with our observation of a higher mean excretion of VMA in the first 2 days com- pared with the rest of the first week of life in both term nonjaundiced and jaundiced groups (Table I). As suggested by von Studnitz (1960) in the case of VMA, the high output after birth in the term nonjaundiced group might reflect a rise in catecholamine production following the stress of birth. This view is in fact supported by the indirect evidence of Howard, McDevitt, and Stander (1964), who observed an increase in catecholamine excretion in the first urine specimen passed after birth by infants delivered by forceps compared with those delivered spontaneously by caesarean section. The absence of an increase in VMA output after the birth of premature babies (Table I) may be due to the comparative lack of stress accompanying the delivery of these smaller infants. It is interesting that Nicolopoulos et al. (1968) find a higher VMA output on the first day compared with day 15 in term babies but the reverse situation in preterm babies. They suggest that this contrast, which is similar in pattern to our findings, may be related to the rate of maturation of catechol-O-methyltransferase and monoamine oxidase, which may be slower in preterm babies. Though this may be the case, the cause is more likely to be renal in origin, associated with the marked increase in urine volume observed in preterm babies towards the end of the first week of life, particularly as VMA excretion is dependent (see above) on urine flow.

HMPG excretion, which has not previously been recorded for this period of life, bears approximately the same proportional relation to VMA output as in adults when mean values are compared, though the individual measurements are much more widely scattered in the neonate than in the adult.

Tyrosine metabolites. A reduced activity of $p$-hydroxyphenylpyruvic acid ( $p$-HPPA) oxidase is not uncommon in the newborn period of life especially in the premature infant (Kretchmer et al., 1956; Kretchmer and McNamara, 1956; Bloxam et al., 1960). The phenomenon stems either from an actual deficiency of the enzyme (Kretchmer et al., 1956; Kretchmer and McNamara, 1956) or from substrate inhibition (Bloxam et al., 1960), and may usually be corrected by the administration of ascorbic acid (Levine, Gordon, and Marples, 1941; Nitowsky, Govan, and Gordon, 1953), 2,6-dichlorophenolindophenol (Hager, Gregerman, and Knox, 1957), or folic acid (Nitowsky et al., 1953; Menkes and Avery, 1963). The condition is characterized by raised blood tyrosine concentration (tyrosinaemia) (Mathews and Partington, 1964; Wong et al., 
1967; Partington, 1968) and increased excretion of both tyrosine and its metabolites, p-HPLA, $p$-HPPA, and $p$-hydroxyphenylacetic acid (tyrosyluria) (Bloxam et al., 1960; Woolf, 1965; Partington, 1968).

Reports on the incidence of tyrosyluria and its association with tyrosinaemia vary mainly because of the greater sensitivity of methods used to estimate blood tyrosine concentration compared with those employed to diagnose tyrosyluria. In a survey of 1276 infants aged 3 to 8 weeks, Gibbs and Woolf (1959) found 14 cases of tyrosyluria using ferric chloride, while in another survey of 120 infants, screening urines by paper chromatography, which is more sensitive than ferric chloride, Woolf (1965) detected 26 cases of tyrosyluria. Early reports by Levine and his co-workers (Levine, Marples and Gordon, 1941) that tyrosyluria occurs only in the premature baby were later found to be incorrect (Wong et al., 1967). Partington (1968), in a survey of 123 neonates under the age of 4 weeks, found that the incidence of tyrosyluria is closely related to tyrosinaemia if the blood tyrosine is greater than $10 \mathrm{mg} / 100 \mathrm{ml}$, but that the relation is less constant when the tyrosine level is below this value. It is surprising that the correlation between these two conditions is not strong since one is a direct consequence of the other. Although tyrosinaemia has been quantitatively defined (Partington, 1968), tyrosyluria has not because of scanty information about $p$-HPLA and $p$-HPPA excretion and semiquantitative methodology. Woolf (1965) reported values of about $1200 \mu \mathrm{g} p$-HPPA and 3500 $\mu \mathrm{g} p$-HPLA/mg creatinine in cases classified as tyrosyluria, while Coward and Smith (1968) gave values of $p$-HPLA greater than $500 \mu \mathrm{g} / \mathrm{mg}$ creatinine in a study of 6 similar patients. A patient investigated by Crawhall et al. (1971), who measured $p$-HPLA output by gas chromatography-mass spectrometry, excreted less (60-366 $\mu \mathrm{g} p$-HPLA/ mg creatinine). Using gas chromatography alone, Melançon et al. (1974) found an excretion of 1191 $\mu \mathrm{g} p$-HPLA/mg creatinine in a baby with a blood tyrosine of $31.5 \mathrm{mg} / 100 \mathrm{ml}$. These values are greater than most of those observed in the present series (Tables I and II). By virtue of its stability compared with $p$-HPPA, $p$-HPLA is a more useful index of tyrosyluria. Excretion of $1 \mathrm{mg} p$-HPLA/ $24 \mathrm{~h}$ is tentatively proposed here as the upper limit of normal since this level was not exceeded in the term nonjaundiced group of infants.

Defining the condition in this somewhat arbitrary way, its incidence in infants during the first week of life was found to be higher in the present series than any previously reported study, about
$27 \%$ of the neonatal population. This figure was calculated on the assumption that the infants studied, who were chosen at random, were representative of the population from which they were drawn. However, such an assumption may not be entirely justified. Wong et al. (1967) showed that the incidence of tyrosinaemia in a group of term infants was nearly twice as high in males as in females, and in our series males outnumbered females 6:1. Wong et al. also found that the incidence of tyrosinaemia was greater in infants fed with cow's milk and in those without vitamin C supplement; the nature of the feed was not recorded in the present study. It should be noted, however, that the sensitivity of the gas chromatographic procedures employed is higher than that of other available methods. It is entirely possible, therefore, that the higher incidence observed in our studies related, at least in part, to this factor. Using conventional screening tests (Perry, et al., 1966), the majority of our subjects were classed as nontyrosyluric (Phenistix test). Measurements of this type can hardly be considered as academic, however, since the findings of Menkes et al. (1972) have indicated that raised blood tyrosine concentration, which tyrosyluria is related to, may, under certain circumstances, result in some degree of intellectual impairement.

Tyrosine intake in the diet is probably responsible for the increased excretion of p-HPLA observed during days 3-7 compared with the first 48 hours in both jaundiced and nonjaundiced babies (Table I). That this change was not significant in the jaundiced groups may indicate that $p$-HPPA oxidase may mature more slowly in these cases. Melançon et al. (1974) observed a greater output of $p$-HPLA ( $\mu \mathrm{g} / \mathrm{mg}$ creatinine) on day 5 compared with the first day of life in term infants, though this was probably not significant. Their values, like those for HVA excretion, are higher than those we found.

Prematurity is linked with a significant increase in the excretion of $p$-HPLA during both periods $(\mathrm{P}<0.025$, days 1 and $2 ; \mathrm{P}<0.001$, days $3-7)$ in the first week (Table II). Partington (1968) observed a bimodal distribution of plasma tyrosine levels in newborn infants, more marked in the premature than the term baby. Jaundice may be an important factor in this distribution. The increased incidence of tyrosyluria in the premature probably arises from slower maturation of $p$-HPPA oxidase in these babies compared with term infants. This may be present to an even greater degree in premature babies who develop jaundice, as $p$-HPLA output is greater in the latter. The 
absence of an effect of jaundice on p-HPLA excretion in term babies in our series may indicate that the more mature enzyme is no longer the ratelimiting factor in this pathway of tyrosine metabolism, though it is conceivable that maturity alone is not the only reason and that an inhibitory action of bilirubin on enzyme activity may have a demonstrable effect when enzyme activity is low. Such apparent inhibition might explain the lag observed between the disappearance of jaundice (usually within the first week) and tyrosyluria or tyrosinaemia (usually at 6 weeks) (Partington, 1968) as representing the time required for the production of fresh enzyme. However, a tendency suggested above, for p-HPPA oxidase to be immature, in common with the enzyme responsible for bilirubin conjugation, uridine glucuronyl transferase (Brown and Zuelzer, 1958; Lathe and Walker, 1958), is a more likely explanation for tyrosyluria in the newnewborn period of life and its association with jaundice.

\section{REFERENCES}

Anders, D., Kindermann, G., and Pfeifer, U. (1973). Metastasizing fetal neuroblastoma with involvement of the placenta stimulating fetal erythroblastosis. Fournal of Pediatrics, 82, 50.

Applegarth, D. A., Hardwick, D. F., and Ross, P. M. (1968) Creatinine excretion in children and the usefulness of creatinine equivalents in amino acid chromatography. Clinica Chimica Acta, 22, 131.

Avery, M. E., Clow, C. L., Menkes, J. H., Ramos, A., Scriver, C. R., Stern, L., and Wasserman, B. P. (1967). Transient tyrosinemia of the newborn : dietary and clinical aspects. Pediatrics, 39, 378.

Berlyne, G. M. (1965). Endogenous creatinine clearance and the glomerular filtration rate. American Heart fournal, 70, 143.

Bloxam, H. R., Day, M. G., Gibbs, N. K., and Woolf, L. I. (1960). An inborn defect in the metabolism of tyrosine in infants on a normal diet. Biochemical fournal, 77, 320.

Boehm, J. J., and O'Brien, D. (1963). The urinary excretion of 3-methoxy-4-hydroxy-mandelic acid (VMA) in newborn infants with the respiratory distress syndrome. Pediatrics, 31, 861.

Brett, E. M., Oppé, T. E., Ruthven, C. R. J., and Sandler, M. (1964). Congenital dopamine-secreting neuroblastoma with clinical and biochemical remission. Archives of Disease in Childhood, 39, 403.

Brown, A. K., and Zuelzer, W. W. (1958). Studies on the neonatal development of the glucuronide conjugating system. Fournal of Clinical Investigation, 37, 332.

Calne, D. B., Karoum, F., Ruthven, C. R. J., and Sandler, M. (1969). The metabolism of orally administered L-dopa in parkinsonism. British fournal of Pharmacology, 37, 57.

Coward, R. F., and Smith, P. (1968). Urinary excretion of 4hydroxy-phenyllactic acids and related compounds in man including a screening test for tyrosyluria. Biochemical Medicine, $2,216$.

Cramér, K., Cramér, H., and Selander, S. (1967). A comparative analysis between variation in 24-hour urinary creatinine output and 24-hour urinary volume. Clinica Chimica Acta, 15, 331.

Crawhall, J. C., Mamer, O., Tjoa, S., and Claveau, J. C. (1971). Urinary phenolic acids in tyrosinemia. Identification and quantitation by gas chromatography-mass spectrometry. Clinica Chimica Acta, 34, 47.

Gibbs, N. K., and Woolf, L. I. (1959). Tests for phenylketonuria: results of a one-year programme for its detection in infancy and among mental defectives. British Medical fournal, 2, 532.

Gitlow, S. E., Mendlowitz, M., Wilk, E. K., Wilk, S., Wolf, R. L., and Bertani, L. M. (1968). Excretion of catecholamine cata- bolites by normal children. Fournal of Laboratory and Clinical Medicine, 72, 612

Gjessing, L. R. (1966). Studies of urinary phenolic compounds in man. V. Homovanillic and vanillylmandelic acids in children without functional neural tumors. Scandinavian fournal of Clinical and Laboratory Investigation, 18, 540.

Hager, S. E., Gregerman, R. I., and Knox, W. E. (1957). p-Hydroxyphenyl-pyruvate oxidase of liver. Fournal of Biological Chemistry, 225, 935.

Hare, R. J. (1950). Endogenous creatinine in serum and urine. Proceedings of the Society of Experimental Biology and Medicine 74, 148.

Howard, W. F., McDevitt, P. I., and Stander, R. W. (1964). Catecholamine content of the initial voided urine of the newborn. American fournal of Obstetrics and Gynecology, 89, 615.

Karoum, F., Anah, C. O., Ruthven, C. R. J., and Sandler, M. (1969). Further observations on the gas-chromatographic measurement of urinary phenolic and indolic metabolites. Clinica Chimica Acta, 24, 341.

Karoum, F., Ruthven, C. R. J., and Sandler, M. (1968). Gas chromatographic measurement of phenolic acids and alcohols in human urine. Clinica Chimica Acta, 20, 427

Knox, W. E. (1972). Phenylketonuria. Metabolic Basis of Inherited Disease, 3rd ed., p. 266. Ed. by J. B. Stanbury, J. B. Wyngaarden, and D. S. Fredrickson. McGraw-Hill, New York.

Kretchmer, N., and McNamara, H. (1956). Certain aspects of tyrosine metabolism in the young. II. The tyrosine oxidizing system of fetal rat liver. Fournal of Clinical Investigation, 35, 1089.

Kretchmer, N., Levine, S. Z., McNamara, H., and Barnett, H. L. (1956). Certain aspects of tyrosine metabolism in the young. I. Development of the tyrosine oxidizing system in human liver. fournal of Clinical Investigation, 35, 236.

La Du, B. N., and Gjessing, L. R. (1972). Tyrosinosis and tyrosinemia. Metabolic Basis of Inherited Disease, 3rd ed., p. 296. Ed. by J. B. Stanbury, J. B. Wyngaarden, and D. S. Fredrickson. McGraw-Hill, New York.

Lathe, G. H., and Ruthven, C. R. J. (1958). Factors affecting the rate of coupling of bilirubin and conjugated bilirubin in the van den Bergh reaction. Fournal of Clinical Pathology, 11, 155.

Lathe, G. H., and Walker, M. (1958). The synthesis of bilirubin glucuronide in animal and human liver. Biochemical fournal, 70, 705.

Levine, S. Z., Gordon, H. H., and Marples, E. (1941). A defect in the metabolism of tyrosine and phenylalanine in premature infants. II. Spontaneous occurrence and eradication by vitamin C. fournal of Clinical Investigation, 20, 209.

Levine, S. Z., Marples, E., and Gordon, H. H. (1941). A defect in the metabolism of tyrosine and phenylalanine in premature infants. I. Identification and assay of intermediary products. fournal of Clinical Investigation, 20, 199.

Light, I. J., Sutherland, J. M., Loggie, J., and Berry, H. (1971). Defect in synthesis of epinephrine in premature infants with tyrosinemia. Metabolism, 20, 247.

McCance, R. A. (1959). The maintenance of stability in the newly born. I. Chemical exchange. Archives of Disease in Childhood, 34, 361.

McCance, R. A., and Widdowson, E. M. (1954). Normal renal function in the first two days of life. Archives of Disease in Childhood, 29, 488.

Mathews, J., and Partington, M. W. (1964). The plasma tyrosine levels of premature babies. Archives of Disease in Childhood, 39, 371 .

Melançon, S. B., Grignon, B., Dallaire, L., and Potier, M. (1974). Étude par chromatographie gazeuse des acides organiques et sériques chez le nouveau né. L'Union Médicale du Canada, $103,678$.

Menkes, J. H., and Avery, M. E. (1963). The metabolism of phenylalanine and tyrosine in the premature infant. Bulletin of Johns Hopkins Hospital, 113, 301.

Menkes, J. H., Welcher, D. W., Levi, H. S., Dallas, J., and Gretsky, N. E. (1972). Relationship of elevated blood tyrosine to the ultimate intellectual performance of premature infants. Pediatrics, 49, 218.

Nicolopoulos, D., Agathopoulos, A., Danelatou-Athanassiadou, C., and Bafataki, M. (1968). Urinary excretion of phenolic and indolic compounds, metacatecholamines, and VMA by fullterm and premature infants. Pediatrics, 41, 777. 
Nitowsky, H. M., Govan, C. D., and Gordon, H. H. (1953). Effect of hemopoietic and other agents on the hydroxyphenyluria of premature infants. American fournal of Diseases of Children 85, 462.

Partington, M. W. (1968). Neonatal tyrosinaemia. Biologica Neonatorum, 12, 316.

Perry, T. L., Hansen, S., and MacDougall, L. (1966). Urinary screening tests in the prevention of mental deficiency. Canadian Medical Association Fournal, 85, 89.

Pisano, J. J., Crout, J. R., and Abraham, D. (1962). Determination of 3-methoxy-4-hydroxymandelic ocid in urine. Clinica Chimica Acta, 7, 285.

Pscheidt, G. R., Berlet, H. H., Spaide, J., and Himwich, H. B. (1966). Variations of urinary creatinine and its correlation to excretion of indole metabolites in mental patients. Clinica Chimica Acta, 13, 228.

Ruthven, C. R. J. (1965). Studies on catecholamine metabolism in man: the urinary excretion of 4-hydroxy-3-methoxymandelic acid (VMA) in the newborn, p. 165. Ph. D. Thesis, University of London.

Smith, C. A. (1959). Fetal and neonatal nutrition: assimilation and metabolism of specific food substances. The Physiology of the Newborn Infant, 3rd ed., p. 251. Blackwell, Oxford.

Stern, L., Greenberg, R. E., and Lind, J. (1961). Catecholamine excretion in the newborn period: effect of short periods of induced hypoxia. Acta Paediatrica, 50, 497.

Vestergaard, P., and Leverett, R. (1958). Constancy of urinary creatinine excretion. Fournal of Laboratory and Clinical Medicine, 51, 211. von Studnitz, W. (1960). Methodische und klinische Untersuchungen über die Ausscheidung der 3-Methoxy-4-hydroxymandelsăure im Urin. Scandinavian fournal of Clinical and Laboratory Investigation, 12 (Suppl. 48), 30.

von Studnitz, W. (1962). Utber die Ausscheidung der 3-Methoxy4-hydroxy-phenylessigsăure (Homovanillinsăure) beim Neuroblastom und anderen neuralen Tumoren. Klinische Wochenschrift, 40, 163.

Voorhess, M. L. (1967). Urinary catecholamine excretion by healthy children: I: Daily excretion of dopamine, norepinephrine, epinephrine, and 3-methoxy-4-hydroxymandelic acid. Pediatrics, 39, 252.

Wong, P. W. K., Lambert, A. M., and Komrower, G. M. (1967). Tyrosinaemia and tyrosyluria in infancy. Developmental Medicine and Child Neurology, 8, 551.

Woolf, L. I. (1965). Infants lacking p-hydroxyphenylpyruvate hydroxylase. Symposium on Tyrosinosis, p. 24 . Ed. by L. R. Gjessing. Scandinavian University Books, Oslo.

Zeisel, H., and Kuschke, H. J. (1959). Die Catechinamine Adrenalin and Noradrenalin im Harn des Kindes. Klinische Wochenschrift, 37, 1168.

Correspondence to Professor M. Sandler, Queen Charlotte's Maternity Hospital, Goldhawk Road, London W6 OXG. 